\title{
CORRESPONDENCE
}

\section{Stanley Fish and the Future of Pragmatism in Legal Theory}

\author{
Sotirios A. Barber†
}

Stanley Fish's recent book review ${ }^{1}$ measures Richard Posner's The Problems of Jurisprudence ${ }^{2}$ more by the importance of the questions it raises than by the coherence of its answers. That standard enables Professor Fish to rank Judge Posner's book with the best of post-war legal thought ( $p$ 1475). The same standard demands a similar assessment of Fish's review. Few writings match the economy and punch with which it points legal theory in the right direction. Fortunately for all of us-including Fish-the right direction is not the one he says he favors.

\section{Fish on Posner's Almost Pragmatism}

The heart of Fish's review is that the genuinely pragmatist part of Posner's thought-Posner's pragmatist account of legal phenomena-gives "the right answer" to the question of "how the law works" (pp 1447-57), but that Posner's pragmatist program for reforming legal practice lapses into philosophic stances ("foundationalism," "metaphysics," "essentialism") $)^{3}$ whose usefulness mod-

+ Professor of Government, University of Notre Dame.

' Stanley Fish, Almost Pragmatism: Richard Posner's Jurisprudence, 57 U Chi L Rev 1447 (1990). All parenthetical page numbers in the text refer to this article.

2 Richard A. Posner, The Problems of Jurisprudence (Harvard, 1990).

3 For present purposes I shall adopt the terminology of Fish's review. In particular, by "essentialism" I shall refer, as Fish seems to, not just to moral and scientific realism, but to any metaphysics, including conventionalism and even skepticism. Fish's usage enables me to avoid issues that are irrelevant for present purposes. It is also justified by what I consider a true moral argument, which I can sketch here while deferring its elaboration to a work in progress. Persons who take argumentative positions implicitly agree to abandon their positions in the presence of better arguments on the other side. Anti-realist participants in metaphysical debate-i.e., responsible anti-realists-therefore join in the characteristically realist assumptions regarding the potential fruitfulness of metaphysical debate. Anti-realist metaphysicians thus concede much to the realist position. By the same argument, realists 
ern pragmatists deny (pp 1456-60). Fish applauds Posner's contention that all forms of objectivity, scientific as well as legal-moral, are political achievements- "just a matter," says Fish, "of how much homogeneity the powers that be have managed to achieve" (p 1449). He agrees with Posner that justice under law is merely rhetorical rationalization of personal preference; in what Fish calls "the (real) world," a world governed not by reason and law but by accident and "force," judges are bound only by whatever "ramshackle" argumentative resources happen to work politically (pp 1449-53). Fish agrees that the "chief goals" of legal theory are hopeless because the quest for normative and predictive theories of judicial choice ignores the reality that "personal values are impervious to argument" and that judges change their minds "not by a process of 'reasoned exposition," " but by a fundamentally unpredictable "emotional switch from one non-rational cluster of beliefs to another" (p 1455). ${ }^{4}$

But Fish is not happy with Posner's failure to be consistently pragmatist, a failure evident in Posner's - assumption that pragmatists can argue from a descriptive account of law to a normative program for law. Posner wants to orient judicial discussion "away from issues semantic and metaphysical and toward issues factual and empirical"-away from "intangibles such as ... human dignity ... justice and fairness ... and the ... ideals or intentions of the framers" and toward goals like fewer "bankruptcies and lower interest rates." Fish places Posner's program in the reformist tradition of the American Legal Realists, who preached, in Fish's words, that a "pro-scientific, no-nonsense empiricism" could replace a concern for "substanceless" notions and enable judges to rise above their partisan biases (pp 1457-59). If that should happen, says Fish, "we will not have escaped semantics (merely verbal entities) and metaphysics (faith-based declarations of what is), but merely attached ourselves to new versions of them" ( $p$ 1461). We shall have merely gone "from one essentialism, identified with natural law or conceptual logic, to another, identified with the strong empiricism of the social sciences" ( $p$ 1459).

cannot responsibly close themselves to the possibility that realism is mistaken and that antirealists have a share in what we may naively be calling "truth."

I also follow Fish on the meaning of "pragmatism." As we shall see, this is an account of law that purports to be above metaphysics and epistemology and conceives all forms of objectivity as rhetorical constructs in the service of rationally groundless preferences.

" "Reasoned exposition" and "emotional switch" are quotations from Posner, The Problems of Jurisprudence at 150 (cited in note 2).

- Id at 122-23, 387. 
Moreover, says Fish, Posner's reforms would result not in "a more empirically rooted law, but no law at all" (1461). What Posner calls the metaphysical "illusions" of law Fish calls "the assumptions ... that constitute" political communities, the roles of their officials, and the "very identity" of their members (p 1463). Fish denies that law emerges from a desire for goals that can be measured or defined in scientific terms. "Law emerges," says Fish, "because people desire predictability, stability, equal protection, the reign of justice, etc., and because they want to believe that it is possible to secure these things by instituting a set of impartial procedures." One cannot reform law by ridding it of references to the notions that constitute it (pp 1462-63). The law "will only work-not in the realist or economic sense but in the sense answerable to the desires that impel its establishment-if the metaphysical entities Posner would remove are retained," and "they will be retained, no matter what analysis of either an economic or deconstructive kind is able to show" (p 1462).

Fish's confidence that these assumptions "will be retained" stems from an important expression of his pragmatist view, something he calls "Fish's first law of tolerance dynamics." Fish announces this law while playfully deconstructing Richard Rorty's assumption that pragmatism's anti-foundationalism can help bring about a society whose members will share a more inclusive sense of community borne of greater toleration of racial, moral, and other differences (pp 1465-66). Rorty thus joins Posner in the class of pragmatists who sometimes forget "that there is absolutely nothing you can do with pragmatism" and that social change just happens and "cannot be planned" (pp 1464-66). Rorty also seems to have a less than purely pragmatist understanding of the conditional nature of toleration. Fish illuminates the latter through a sort of confession about his personal reactions to the scholarly works of others. He reveals that he can listen without prejudgment only when he has no scholarly investment in the matter under discussion. Where he has taken a position, that position is "inseparable from my sense of my career and therefore from my sense of myself," and "as I listen (not after I listen) I perform involuntary acts of approval ... [and] disapproval." Armed with this "example," Fish proclaims his first law of tolerance dynamics: "Tolerance is exercised in an inverse proportion to there being anything at stake" (pp 1466-67).

Fish later deploys his first law against Posner's denial of law's autonomy as a field and Posner's approval of an interdisciplinary legal theory that makes use of materials from economics and other 
sciences. ${ }^{6}$ Fish acknowledges that no field can avoid some dependence on the "assumptions and materials" of other fields, but he maintains that each field has a unique purpose, and that this purpose determines the ways in which outside materials are ingested and used (pp 1469-70). Fields thus exhibit a "natural conservatism" or "survival instinct" that works to "prevent the borrowed material from overwhelming the borrower" ( $p$ 1470). This survival instinct makes the various fields "institutional illustrations of Fish's first law" ( $p$ 1470). The function of law as a field is to provide "rhetorical constructions" (like "justice, fairness, and human dignity") for presenting groundless preferences "as the natural outcomes of abstract impersonal imperatives" ( $p$ 1473). If the language of science replaced the language of law, "[w]e would no longer be able to say 'what justice requires' or 'what fairness dictates' and then fill in those phrases with the courses of action we prefer ..." (p 1473). The "survival instinct" that explains Fish's first law is not about to let that happen-hence Fish's confidence that the law's illusions "will be retained." And that is just as well, for a move from law to science would be from one illusion to the next, and other fields have other aims served by "vocabularies that do not so much hook up with the world as declare one" (p 1473). So much for the "essentialist" assumption in Posner's call for an interdisciplinary approach to law, the assumption of one world with each discipline seeking the empirical truth about some kind of thing in that world ( $p$ 1473).

\section{Fish AND ANTI-PRAgmatism}

Observers who believe there is a persuasive case for the existence of at least some more or less knowable "outside" (theoryindependent) realities - physical realities or social realities or legalmoral realities or any combination thereof-will welcome Fish's showing that pragmatist programs for law are incoherent. Indeed, some anti-pragmatists will want to extend the favor to pragmatism's account of law. Fish anticipates and tries to block this move. To show that he does not succeed I shall first outline an anti-pragmatist rejoinder to his arguments.

One might begin by noticing that Posner is not the only pragmatist who lapses into an assumption of one real world whose parts are describable in general terms from a general perspective. The same assumption is evident in Fish's categorical statements

- Discussing id at $424-33,437-41,455-56$. 
concerning "the bottom-line fact of the human condition" (irreducible differences and partial perspectives, pp 1455, 1464, 1468, 1474) and the chief constitutive facts of all fields of human endeavor (core purposefulness and survival-oriented pattern of change as per Fish's first law, pp 1469-70). Nor are Posner and Rorty alone in assuming that something follows from pragmatism: Fish assumes the same when criticizing pragmatist programs.

Even if Fish could remain a pure pragmatist by noting the anti-pragmatism of all pragmatist programs (something I'll deny in a moment), criticizing such programs implies a rule against misrepresenting pragmatism, and since such a rule would be something more than "absolutely nothing," it would contradict the pure pragmatist tenet that "absolutely nothing" of practical significance follows from pragmatism ( $p$ 1464). Fish may thus contravene pragmatism's two-fold anti-foundationalism by suggesting that pragmatism enjoys a foundation and that it can serve as the foundation of some norm. Fish anticipates the first of these criticisms by denying that pragmatism contradicts itself by having a "foundational premise." His surprising response to the second is that he doesn't advocate pragmatism. Let us look closely at these answers.

Fish holds the "basis of all pragmatist thinking" to be "the condition ... of heterogeneity or difference" ( $p$ 1454). On the problem that this statement poses for pragmatism, Fish says: "The fact that pragmatism too has its foundational premise is not a contradiction of its anti-foundationalism because this particular premise-the irreducibility of difference-is anti-foundationalism" ( $p$ 1454). But in the very next sentence, as throughout his review, Fish refers to more than a premise (a verbal entity that serves an inference-generating function) - Fish refers to the world, and in a perfectly general and categorical way:

In a heterogeneous world, a world in which persons are situated-occupying particular places with particular purposes pursued in relation to particular goals, visions, and hopes as they follow from holding (or being held by) particular beliefs-no one [regardless of her beliefs?] will be in a situation that is universal or general (that is, no situation at all), and therefore no one's perspective ... can lay claim to privilege. ( $p$ 1454)

"Fish, 57 U Chi L Rev at 1451 ("the (real) world" of judicial practice); 1453 (human constitution as mortal and limited); 1474 ("bottom-line fact of the human condition"); 1457 ("Posner's strongest insights," as compared to his mistakes); 1466 (Fish's first law); 1469 (pragmatism "can best describe the law"); 1470 ("the natural conservatism of disciplines") (cited in note 1). 
He goes on to say that "[i]n that kind of world-a world of difference-the stipulation both of what is (of the facts) and of what ought to be will always be [always? even on the occasion of this statement?] a politically angled one, and in the (certain) event of a clash of stipulations, the mechanisms of adjudication, whether in the personal or institutional realms, will be equally political" ( $p$ 1454). These remarks show that despite Fish's disclaimer, his pragmatism seems grounded in what purports to be a true description of the world, not merely his personal perspective on the world.

Pragmatism may be able to avoid a grounding in reality by proceeding from its internal stipulations; I won't question that assumption here. But pragmatism can't claim anti-foundationalism if its basic premise is held to hook up with the real world. So Fish will have to say that his apparent statements about the world are actually mere stipulations, insupportable by anything common sense would describe as "evidence" (of the truth) or a "reason" (to believe true). And that seems to be what Fish tries to do. Toward the end of his review he reiterates that "the bottom-line fact of the human condition" is that of "a creature whose perspective is not general . . . but partial" ( $p$ 1474). But now he adds something new; now he says that the partiality of the human condition "can never be experienced as such, and those who think it can be unwittingly reinstate the objective viewpoint they begin by repudiating" ( $p$ 1474). Fish sees, in other words, that it is only from some Archimedean point or God's-eye view that we could objectively know that there is no Archimedean point or God's-eye view. Accordingly, Fish strives for pragmatist purity by disclaiming any real-world grounding for pragmatism's view of the world. That view is no less "political" than any other.

If pure pragmatism is no less a matter of political stipulation than its alternatives, why prefer it to some form of anti-pragmatism? Rorty treats modern pragmatism as orthodoxy in current legal thought. ${ }^{8}$ But even granting arguendo that there is something of a consensus among a particular group of writers, consensus translates into truth only if you accept a conventionalist metaphysics that good pragmatists refuse to acknowledge, much less defend. And one can surely disagree with Rorty that pragmatism enjoys anything one can legitimately call a consensus. Aside from such

\footnotetext{
${ }^{8}$ Richard Rorty, The Banality of Pragmatism and the Poetry of Justice, $63 \mathrm{~S}$ Cal L Rev 1811, 1811-13 (1990).
} 
problems as what true pragmatism might be, ${ }^{8}$ there is the problem of how to classify ostensible critics of pragmatism, ${ }^{10}$ and Rorty himself grudgingly mentions a moral-realist anti-pragmatism ${ }^{11}$ that several current observers see as a major alternative response to the problems of post-war constitutional theory. ${ }^{12}$ Nor can one claim a pragmatist consensus in the community beyond the academy, the community pragmatists say they would liberate from abstract academic theorizing. Fish is aware of pragmatism's departure from common sense regarding things like the physical world, reason, justice, and the rule of law. ${ }^{13}$ Nor can an anti-foundationalist like Fish claim that pragmatism's insights are self-evident. Even if we could assume it self-evident that there are no Archimedean points and God's-eye views, these metaphors compete with other metaphors. Why not construe the human condition in terms of aspirational quests for ends (like health, justice, truth) that we can glimpse and get closer to without fully grasping-ends whose general attractiveness justifies the conditions (openness, diversity, toleration, experimentation, certain material conditions of life) that may be essential to a meaningful quest? ${ }^{14}$

In addition, some philosophers argue that an admittedly partial and fallible view of what might appear to someone as real-Medusa, dark matter, $\mathrm{NaCl}$, Bachman's Warbler, an intention, cruelty, justice, a UFO, or what have you-can sometimes be best explained by the hypothesis that it actually exists. ${ }^{16}$ Whatever

- For a recent discussion of the varieties of pragmatism, see Steven D. Smith, The Pursuit of Pragmatism, 100 Yale L J 409 (1990).

${ }^{10} \mathrm{Id}$ at 414-20 (proposing that Dworkin is best interpreted as a closet pragmatist, but conceding that Dworkin may intend to be the anti-pragmatist he at least pretends to be).

"Rorty, $63 \mathrm{~S}$ Cal L Rev at $1813 \mathrm{n} 13$ (cited in note 8), citing Michael S. Moore, $A$ Natural Law Theory of Interpretation, 58 S Cal L Rev 279 (1985). For a more recent and direct attack on contemporary pragmatism that singles out Rorty and Fish, see Michael S. Moore, The Interpretive Turn in Legal Theory: A Turn for the Worse?, 41 Stan L Rev 871, 892-917 (1989).

12 See, for example, Smith, 100 Yale L J at 447-49 (cited in note 9); Graham Walker, Moral Foundations of Constitutional Thought chs 1-2 (Princeton, 1990).

13 Fish, 57 U Chi L Rev at 1449-50 (rejecting the idea of justice as unprejudiced application of general rules to different persons); 1451 (rejecting the "popular picture" of good reasoning as beliefs controlled by evidence); 1452 (acknowledging the "shocking" quality of the view that force is ultima ratio); 1462-63 (affirming that law emerges and sustains itself because people desire things, like justice, that pragmatism exposes as mere rhetorical constructs) (cited in note 1).

14 See Sotirios A. Barber, On What the Constitution Means chs 2-5 (Johns Hopkins, 1984), elaborating the implications of aspirational thinking for constitutional theory.

13 For representative attempts to reconcile a moral-scientific realism and an epistemology that denies self-evident truths and unmediated perceptions of reality, see David 0 . Brink, Moral Realism and the Foundation of Ethics ch 5 (Cambridge, 1989); Richard N. 
the soundness of these and other anti-pragmatist claims, their very existence-is evidence against any suggestion that consensus or selfevidence supports pragmatism. And if Force, the Fish-Posner ultima ratio, had successfully supported pragmatism, we'd have either the consensus or the self-evidence we don't seem to have.

Because pragmatism is grounded neither in evidence nor in beliefs too deeply embedded in our identity to question, one may perhaps be a pragmatist (I won't take a position on that possibility here), but one cannot advocate pragmatism. For, I assume, to advocate pragmatism is to cite evidence for it, evidence is thought to be evidence of truth, and Fish denies that we can have such evidence (pp 1451-55, 1468). So it should not have taken us totally by surprise to hear Fish say that he himself has "never been" an advocate of pragmatism ( $p$ 1465). This leaves him with one answer to the charge that he pursues a pragmatist program in spite of himself. He can say that he is merely noting the Posner-Rorty lapses into essentialism, not criticizing or advising Posner and Rorty against such lapses.

But why should Fish want to note the Posner-Rorty lapses? And why assume readers will be interested? Surely not just because Fish wants to report the truth and others want to hear it. Allowing an interest in truth qua truth would explode pragmatism's understanding of both truth and the human condition -hence Fish's attempt to escape contradiction by assuring readers that he prejudges all scholarly issues in which he has a personal interest (pp 1466-67). There must be something other than truth that moves Fish to note the Posner-Rorty lapses. Let's consider two options, beginning with one he can share with the community at large. In order for a motivation to constitute a public purpose-one we would all want to pursue in common-it would have to involve a reason in both the instrumental and teleological senses of "a reason." Fish would have to assume that noting the PosnerRorty lapses is (1) instrumental to some end, and (2) the end is one we should all want. Pure pragmatism precludes both assumptions: the first assumption contradicts pure pragmatism's denial that we can have reliable causal knowledge, and the second is an instance of pragmatist advocacy.

The second possibility may be connected to the confession Fish makes when deriving his first law, the confession about prejudging scholarly issues in light of his career commitments (pp

Boyd, How to Be a Moral Realist, in Geoffrey Sayre-McCord, Essays on Moral Realism 181 (Cornell, 1988). 
1466-67). Fish may see his commentary on "almost pragmatism" as a way to enhance his professional reputation. If he keeps that motive to himself, he gives no reason to resist the most plausible account of his commentary-that it is a clear case of pragmatist advocacy. And if Fish discloses the motive, the disclosure's content makes its truth difficult to assess. Were Fish to say he aims not at truth but at the enhancement of his influence, one could wonder how that statement applied to itself.

Such a disclosure would hardly work on pragmatist grounds, for a scholar's reputation is at least conventionally linked to a concern for truth. If Fish reflects on his own analysis of Posner's false hopes for ridding law of its so-called illusions (pp 1463, 1470), he will agree that his reputation and identity as a scholar are connected to the demands of a socially created and supported role that is constituted by "illusions" like truth. The Fish we know would not survive if people took seriously any suggestion that he is incapable of self-criticism and self-sacrifice for the sake of progress toward truth. His survival would depend on construing his confession roughly as follows: "Truth compels me to admit that I sometimes act in self-serving ways, though I'm obviously not doing so now, since it hardly serves my interest to confess occasional prejudice." Now that confession might save Fish because it might indicate his willingness to risk something important-his reputation-for truth. Thus construed, Fish might live and even flourish, but hardly as a pragmatist among pragmatists. Might Fish have expected such a construction of his confession?

In any event, Fish the pragmatist cannot give a reason for his commentary on the Posner-Rorty lapses into essentialism, and that fact leaves intact the most plausible hypothesis: Fish tries to discourage one thing and promote another, thus doing as a pragmatist what he says pragmatists cannot do.

\section{Fish and the Future of Pragmatism}

Anti-pragmatists can concede much to Fish without accepting his attack on metaphysics and the traditional aims of legal-moral philosophy. Accident and force do govern human events to a large extent, if not entirely; and academicians, judges, and others often, if not inevitably, seem more committed to "their" positions than to self-critical striving for agreement or even coherence, much less truth. These conditions make it hard to predict the future of jurisprudence. But participants in academic fora do and must assume the possibility of places where evidence and argument count, and pragmatism won't retain its influence in such places. 
Through his analysis of Posner and Rorty and through his own example, Fish shows that pragmatism is indefensible and incoherent in both its pure and adulterated forms. Discursively and by example he affirms the verdict of his best critic that our so-called pragmatists inevitably rely on metaphysical assumptions. ${ }^{16}$ Coming now as this lesson does from the most challenging of their own theorists-in the form of pragmatism's reductio-responsible pragmatists will either leave jurisprudence or, by explicating and defending their metaphysical beliefs, leave pragmatism and affirm an identity and a conception of flourishing that depends more on self-critical striving for truth than on the willful defense of past errors. The greater number of these erstwhile pragmatists will probably acknowledge their conventionalist metaphysics, the view that what exists is constituted of social convention and that truth is a matter of coherence among shared beliefs, not correspondence to an outside reality. ${ }^{17}$ But responsible theorists will be less interested in stubborn assertions of their current views than in testing their beliefs through argument with their critics. And that attitude could find some erstwhile pragmatists moving toward positions other than conventionalism, including moral skepticism and even moral realism, the view that there are right answers in hard cases and that legal-moral terms (like "due process") can refer to real moral entities approachable through better theories of their nature.

Metaphysical debate among legal theorists can be expected to strengthen the moral realist approach to law and therewith the case for activist judges like John Marshall and Earl Warren. ${ }^{18}$ Defending this suggestion means going through all of the modern arguments for and against moral realism in legal-moral theory, something I cannot do here. ${ }^{19}$ But Fish's review indicates some grounds for optimism among moral realists. Fish's reductio of pragmatism should leave three contending metaphysics in jurisprudence: legalmoral realism, legal-moral skepticism, and legal-moral conventionalism. Fish's reflections on the skeptical element in pragmatism show why legal-moral skeptics cannot responsibly participate in

\footnotetext{
${ }^{16}$ See Moore, 41 Stan L Rev at 892-917 (cited in note 11).

${ }^{17}$ Id at 892, 901-03 (arguing that Rorty's anti-foundationalism indicates a conventionalist metaphysics).

${ }^{18}$ See Michael S. Moore, Do We Have an Unwritten Constitution?, 63 S Cal L Rev 107 (1989).

${ }^{18}$ For comprehensive arguments for moral realism in law and ethics, see Brink, Moral Realism and the Foundation of Ethics (cited in note 15); Michael S. Moore, Moral Reality, 1982 Wis L Rev 1061; Moore, 41 Stan L Rev 871 (cited in note 11).
} 
the practice of advising judges: if common values are illusory, advocacy is always rationally groundless and therefore consciously or unconsciously partisan. Fish also shows that conventions unhooked to reality are grounded in either hard or soft forms of force, the antithesis of reason. Fully conscious conventionalists who advise other people are therefore giving "reasons" they know to be mere rationalizations of established power. This leaves the problem of how to advise judges and others to be debated among contending moral realists. They will be the only theorists who have reason to accept the meaningfulness of the questions judges face, questions about the demands of justice and law in hard cases. 
